\title{
СУЧАСНІ ПІДХОДИ ДО ПРОВЕДЕННЯ ПЛАНОВОЇ ІМУНІЗАЦІЇ У ЄВРОПЕЙСЬКИХ КРАЇНАХ
}

\author{
О. В. Гальчук ${ }^{1}$, Т. І. Толокова ${ }^{2}$ \\ ${ }^{1}$ Горохівська иентральна районна лікарня \\ ${ }^{2}$ Тернопільський національний медичний університет \\ імені І. Я. Горбачевського МОЗ Украӥни
}

У статті проаналізовано сучасні підходи до проведення планової імунізації у країнах зарубіжжя та в Україні з визначенням можливих шляхів удосконалення вітчизняної системи імунізації.

\section{MODERN APPROACHES TO THE IMPLEMENTATION OF ROUTINE IMMUNIZATION IN EUROPEAN COUNTRIES}

\author{
O. V. Halchuk ${ }^{1}$, T. I. Tolokova ${ }^{2}$ \\ ${ }^{1}$ Horokhiv Central District Hospital \\ ${ }^{2}$ I. Horbachevsky Ternopil National Medical University
}

The article analyzes modern approaches to conducting routine immunization in countries abroad and in Ukraine to identify possible ways of improving the national immunization system.

Вступ. Одним із найбільш безпечних, економічно обґрунтованих і ефективних засобів запобігання смертності та покращення якості життя населення $\epsilon$ імунізація. У 1974 р. Всесвітньою організацією охорони здоров'я (ВОО3) розпочато створення розширеної програми імунізації з метою зменшення дитячої захворюваності й смертності, збільшення тривалості та покращення якості життя, ліквідації окремих особливо небезпечних інфекцій. У реалізації програми беруть участь майже всі країни-члени ВООЗ, які розробляють і ефективно впроваджують національні програми вакцинопрофілактики. Ефективність вакцинації доведена багаторічним міжнародним досвідом, про що свідчить глобальна ліквідація віспи в усьому світі до 1980 р. [1].

Мета роботи: здійснити порівняльний аналіз сучасних підходів до проведення планової імунізації у країнах зарубіжжя та в Україні з визначенням можливих шляхів удосконалення вітчизняної системи.

Основна частина. За даними ВООЗ, завдяки національним програмам імунізації, що діють у кожній країні, нині рівень охоплення вакцинацією дітей віком до 1 року перевищує 80 \%. Фахівці наголошують, що

(C) О. В. Гальчук, Т. І. Толокова, 2020 успіх національних програм імунізації залежить від цілей та науково обґрунтованої стратегії вакцинації. Поява нових фармацевтичних технологій, посилення ролі держави в питаннях безпеки вакцин, удосконалення процедури їх реєстрації та впровадження у виробництво, необхідність розширення календаря щеплень $\epsilon$ актуальними питаннями державної політики у проведенні вакцинопрофілактики [1, 5].

За час дослідження ми використали дані щодо підходів до планової вакцинації країн Європи, які наведені на офіційному сайті ВООЗ, а також положення вітчизняних законодавчих і нормативно-правових актів, що регламентують проведення планової вакцинопрофілактики в Україні $[9,10]$.

Спочатку провели аналіз законодавчих і нормативно-правових актів, що регламентують проведення імунізації в Україні. За Національним календарем профілактичних щеплень, в Україні передбачена обов'язкова вакцинація за віком проти 10 інфекцій: дифтерії, кашлюка, кору, поліомієліту, правця, туберкульозу, краснухи, епідемічного паротиту, гепатиту В та гемофільної інфекції. За наявності зареєстрованих комбінованих вакцин, до складу яких входять антигени для профілактики інфекцій, що визначені 
календарем, вакцинацію проводять комбінованими вакцинами [2-4, 7].

Проаналізували календарі вакцинації зарубіжних країн, що належать до Європейського регіону ВООЗ, визначили законодавчі засади вакцинопрофілактики. Встановили, що в окремих європейських країнах існує обов'язкове щеплення лише проти однієї чи кількох інфекцій. Так, у Бельгії обов'язковою $є$ вакцинація лише проти поліомієліту; у Франції - проти дифтерії, правця, поліомієліту та туберкульозу; в Італії - проти дифтерії, правця, поліомієліту та гепатиту В; у Словенії - проти дифтерії, правця, кашлюка, поліомієліту, кору, краснухи, гемофільної інфекції та туберкульозу; в Чехії та Угорщині - проти усіх названих інфекцій. У низці країн - Данія, Німеччина, Естонія, Фінляндія, Велика Британія, Люксембург, Нідерланди, Норвегія, Австрія, Швеція, Швейцарія, Іспанія - вибір необхідної імунізації залишається за людиною, незважаючи на наявність раціонально розробленого та затвердженого державою календаря профілактичних щеплень $[6,10]$.

Попри необов'язковість дитячої вакцинації у ряді європейських країн, рівень імунізації населення $\epsilon$ доволі високим завдяки таким факторам, як активна просвітницька діяльність комісій, що пропагують вакцинацію; безоплатне та безперебійне забезпечення вакцинами; потужна державна підтримка біотехнологічної галузі, винайдення нових вакцин та удосконалення наявних, наукові розробки з отримання комбінованих вакцин [8]. Аналізуючи національні календарі щеплень встановили, що в усіх зарубіжних країнах до календарів включені такі соціально небезпечні захворювання, як дифтерія, правець, кір, поліомієліт, епідемічний паротит, кашлюк, краснуха, гепатит В та гемофільна інфекція.

Зважаючи на низький рівень захворюваності на туберкульоз, сьогодні 12 країн Європи відмовились від вакцинації протитуберкульозною вакциною БЦж. Однак ця вакцина залишається включеною у плани вакцинопрофілактики в 41 європейській країні, що становить 77 \% вибірки. Зважаючи на тяжкість перебігу та складність лікування інфекційних захворювань, які викликані менінгококом групи А, вакцинація проти цих інфекцій передбачена календарями 40 \% країн Європи. Щодо захворювань, котрі зумовлені пневмококом Streptococcus pneumoniae, то імунізація проти цього збудника здійснюється у 36 \% країн Європи, календарі яких вивчили. Проти вітряної віспи щеплення здійснюють в 9 країнах (17 \% вибірки), папіломавірусної та ротавірусної інфекцій - у 3 (6 \%) і 2 (4 \%) країнах відповідно [6].

у більшості країн, календарі яких ми досліджували, рекомендують щеплення проти низки інфекційних захворювань. Так, вакцинацію проти грипу рекомендують проводити дітям віком до 2 років, особам віком понад 65 років, особам із хронічними захворюваннями й ослабленим імунітетом, вагітним, працівникам галузі охорони здоров'я, а також людям, які обіймають відповідальні посади. У деяких країнах обов'язковою $\epsilon$ вакцинація проти жовтої лихоманки у разі поїздки до ендемічного району. В Аргентині, Ізраїлі, Китаї, Сполучених Штатах Америки в регулярну імунізацію дітей включена вакцинація проти гепатиту А. 3 розвитком фармацевтичних технологій та появою нових вакцин відбувається постійний перегляд нормативних документів, що встановлюють порядок вакцинопрофілактики у світовій практиці. Так, у календарі багатьох європейських країн включена вакцинація проти менінгококу групи A, пневмококу Streptococcus pneumoniae, ротавірусної та папіломавірусної інфекцій [9-11].

Отже, нині в кожній європейській країні існує власна система вакцинації, що регламентується національними календарями профілактичних щеплень. Незважаючи на певні відмінності, календарі профілактичних щеплень країн Європи мають багато спільного i, як правило, включають здійснення вакцинації проти найбільш соціально значущих і небезпечних інфекцій.

На даний час в Україні передбачена обов'язкова вакцинація за віком проти 10 інфекцій. Однак, на думку експертів та враховуючи рекомендації воОЗ і ЮНІСЕФ, до списку обов'язкових необхідно додати кілька нових щеплень, зокрема проти пневмококу, менінгококу, папіломавірусу людини, грипу. Крім того, перегляд вітчизняного календаря профілактичних щеплень має відбуватись за такими напрямами, як визначення найкращого співвідношення між витратами на імунопрофілактику та ії ефективністю, безпечністю, якістю, враховуючи альтернативні схеми імунопрофілактики; врахування рекомендацій міжнародних організацій та українських науководослідних інститутів для досягнення оптимального рівня імунітету в дітей; підвищення охоплення населення щепленнями шляхом розроблення стратегії, що була б найсприятливішою для пацієнта $[10,11]$.

Відмінністю між законодавчим регулюванням вакцинації в Україні та країнах Європи є те, що в більшості зарубіжних країн вакцинація не є обов'язковою, 
а національні календарі щеплень мають характер рекомендації. Тобто, якщо батьки відмовляються від вакцинації, дітей все ж приймають до виховних, навчальних, оздоровчих та інших закладів. На основі результатів дослідження закордонного досвіду імунопрофілактики виявили низку спільних рис між іноземними та вітчизняним підходами до розв'язання цього питання: наявність обґрунтованих підходів до планової імунопрофілактики населення в економічному, соціальному та медичному аспектах; функціонування у кожній країні національного календаря профілактичних щеплень; затвердження на законодавчому рівні переліку особливо небезпечних інфекційних нозологій, для профілактики яких передбачені щеплення. Однак суттєвою відмінністю зарубіжних і вітчизняного календарів профілактичних щеплень $\epsilon$ те, що в більшості європейських країн вони мають характер рекомендації, і в разі відмови людини від вакцинації, жодні ії громадянські права не порушуються. Українським законодавством передбачається обмеження у відвідуванні дітьми дитячих закладів без

\section{СПИСОК ЛІТЕРАТУРИ}

1. Зверев В. В. Вакцины и вакцинация : национальное руководство ; под ред. В. В. Зверева, Б. Ф. Семенова, Р. М. Хаитова. - М. : ГЭОТАР-Медиа, 2011. - 880 с.

2. Основи законодавства України про охорону здоров'я : Закон України від 19.11.1992 р. № 2801-XII (поточна редакція від 02.03.2014 р., підстава 763-18) [Електронний ресурс]. - Режим доступу : http://zakon2.rada.gov. ua/laws/ show/1658-17.

3. Про затвердження Загальнодержавної програми імунопрофілактики та захисту населення від інфекційних хвороб на 2009-2015 роки : Закон України від 21.10.2009 р. №1658-VI [Електронний ресурс]. - Режим доступу : http:// zakon2.rada.gov.ua /laws/show/1658-17.

4. Про захист населення від інфекційних хвороб : Закон України від 06.04.2000 р. № 1645-ІІІ (поточна редакція від 05.12.2012 р., підстава 5460-17) [Електронний ресурс]. - Режим доступу : http://zakon4.rada.gov.ua/laws/ show/1645-14.

5. Котвіцька А. А. Інфекційна захворюваність в Україні як важлива медико-соціальна проблема / А. А. Котвіцька, О. В. Кононенко, І. В. Кубарєва // Соціальна фармація в Україні: стан, проблеми, перспективи : матеріали Всеукраїнської науково-практичної інтернет-конференції, 3-8 квітня 2013 р. - Харків, 2013. - С. 196-197. наявності довідки про обов'язкові щеплення згідно 3 календарем.

Висновки. Враховуючи визначені тенденції у проведенні планової імунопрофілактики населення в європейських країнах, на нашу думку, в Україні необхідно вжити низку заходів, які покращать вітчизняну систему планової імунопрофілактики населення: удосконалення чинного законодавства, що регламентує проведення імунопрофілактики, зокрема у частині положень відвідування дітьми освітніх закладів у разі відсутності профілактичних щеплень; залучення населення до проведення вакцинації не шляхом закріплення законодавчої норми про їі обов'язковість, а шляхом активної просвітницької роботи, що популяризує цей вид профілактичних заходів; удосконалення методології дослідження стану інфекційної захворюваності в Україні та наукове обґрунтування основних засад формування переліку інфекцій, у тому числі соціально небезпечних, проти яких передбачається планова імунопрофілактика.

6. Мнушко 3. М. Організація імунізації населення за кордоном / 3. М. Мнушко, І. В. Софронова // Клінічна фармація. - 1998. - Т. 2, № 1. - С. 63-67.

7. Про порядок проведення профілактичних щеплень в Україні та контроль якості й обігу медичних імунобіологічних препаратів : наказ МОЗ України від 16.09.2011 p. № 595 [Електронний ресурс]. - Режим доступу : http:// zakon3.rada.gov.ua/laws /show/z1159-11.

8. Платов С. М. Роль комбінованих вакцин у забезпеченні дотримання Календаря профілактичних щеплень в Україні / С. М. Платов, О. О. Заглада, О. А. Мендрік // Клиническая иммунология. Аллергология. Инфектология. - 2011. - № 2 - С. 11-15.

9. Summary: Global immunization coverage in 2012. World Health Organization, 2014. - 4 p.

10. Progress Towards Global Immunization Goals - 2012. Summary presentation of key indicators. Updated July 2013 World Health Organization, 2013. - 19 p.

11. WHO vaccine-preventable diseases: monitoring system. 2013 global summary. [electronic resource]. Access mode : http://apps.who.int/immunization_ monitoring/globalsummary. 